\title{
Virulence Factors of Helicobacter pylori and Their Relationship with the Development of Early and Advanced Distal Intestinal Type Gastric Adenocarcinoma
}

\author{
Bruna Maria Roesler, Sandra Cecília Botelho Costa \\ and José Murilo Robilotta Zeitune \\ State University of Campinas \\ Brazil
}

\section{Introduction}

The first isolation of Helicobacter pylori (H. pylori) in 1980s by Marshall and Warren (Marshall \& Warren, 1984) ushered in a new era in gastric microbiology, and, in conjunction with increased interest in the pathogenesis of gastroduodenal diseases, has led to important breakthroughs in medical care (Dunn et al., 1997).

H. pylori is a spiral-shaped gram-negative flagellate bacterium that demonstrates bluntly rounded ends in gastric biopsy specimens (Goodwin et al., 1987). H. pylori organisms are 2.5 to $5.0 \mu \mathrm{m}$ long and 0.5 to $1.0 \mu \mathrm{m}$ wide, with four to six polar sheathed flagellas, which are essential for bacterial motility (Goodwin \& Armstrong, 1990).

H. pylori was the first pathogenic microorganism that had its genome sequenced in two different strains. In 1997, H. pylori strain 26695 was firstly isolated from an English patient with chronic gastritis and then sequenced. It had a circular chromosome composed of 1.667.867 base pairs (Tomb et al., 1997). In 1999, strain J99 was isolated from an American patient with duodenal ulcer and then sequenced. This presented a similar, overall genomic organization, gene order and prediction of proteomes when compared to strain 26695 (Alm et al., 1999). In 2006, a chronic atrophic gastritis strain, HPAG1, was isolated and sequenced from a Swedish old patient (Oh et al., 2006). More recently, strain G27 was isolated from an Italian patient and had a similar size to the other three strains (Baltrus et al., 2009). Finally, other strains were sequenced, such as Shi470, B128 and 98-10 (McClain et al., 2009; Thiberge et al., 2010).

The finding of strain-specific genes from the comparison of the sequenced strains is in agreement with the earlier studies which demonstrated the high diversity of the $H$. pylori genome (Akopyanz et al., 1992; Han et al., 2003). Consequently, this high level of genetic diversity can be an important factor in its adaptation to the host stomach and also for the clinical outcome of the infection, an aspect that remains unclear. However, it is thought to involve an interplay between the virulence of the infecting strain, host genetics and environmental factors (Kabir, 2009) and experience with other bacterial pathogens suggests that H. pylori-specific factors may exist that influence the microorganism pathogenicity. 
According to Yamaoka (2008), many putative virulence genes of $H$. pylori have been reported to determine clinical outcomes, and these are generally classified into three categories. The first one contains strain-specific genes, which are present in only some $H$. pylori strains. Among them, the best studied is the cag pathogenicity island (PAI), which encodes a bacterial type IV secretory apparatus (Censini et al., 1996). The second group is the phase-variable genes which the gene status can be changed during growth or in different conditions. Based on the comparison of the three first sequenced genomes of $H$. pylori, six genes encoding outer-membrane proteins (oipA, sabA, sabB, babB, babC and hopZ) are thought to undergo phase variation (Tomb et al., 1997; Alm et al., 1999; Oh et al., 2006). The last group of genes is with variable structures and genotypes depending on the strain, as example the vacA gene. Besides, the structure of many genes differs between Western strains and East Asian strains, and the structural differences in some genes are reported to influence virulence (Lu et al., 2007; Yamaoka, 2008). So, in this chapter, among virulence factors are described and analysed urease, vacA, cagA, cagT and dupA genes.

$H$. pylori urease is a potent stimulus of mononuclear phagocyte activation and inflammatory cytokine production (Harris et al., 1996). It appears to function as both a colonization factor and a virulence factor (Dun et al., 1997). The urease C gene, or glmM gene (Foxall et al., 1992), a particular region of the urease gene, is specific to $H$. pylori and can be used for primary identification of the microorganism (Moore et al., 1993). The urease gene can also be used to prove the heterogeneity of $H$. pylori strains. For instance, its heterogeneity can be seen by the diversity of patterns obtained by a restriction fragment length polymorphism (RFLP) of urease $\mathrm{C}$ and urease $\mathrm{B}$ genes, which is able to differentiate many strains presented in diverse pathologies, such as chronic gastritis and peptic ulcer, caused by this bacterium (Roesler et al., 2009).

Other of the major determinants of $H$. pylori virulence is VacA (vacuolating cytotoxin), a toxin that induces cytoplasmic vacuolation in gastric cells (Figura et al., 1989), membrane channel formation, apoptosis and immunomodulation (Atherton et al., 1995; Cover \& Blanke, 2005). The vacA gene is present in all strains and comprises of two variable parts. The s-region encodes the signal peptide and is located at the 5'end of the gene which exists as an s1 or s2 allele, while the m-region (middle) occurs as an $\mathrm{m} 1$ or $\mathrm{m} 2$ allele (van Door et al. 1998). The production of vacuolating cytotoxin is related to the mosaic combination of $s$ and $\mathrm{m}$ allelic types and has been associated to specific genotypes with different outcomes (Telford et al., 1994; van Door et al., 1998).

The cytotoxin-associated gene (cag) pathogenicity island (PAI) is approximately a $40-\mathrm{kb}$ cluster of genes in the H. pylori chromosome and can be divided into two regions, cag I and cag II (Censini et al., 1996), according to a novel insertion sequence. This gene encodes a type IV secretion system, which delivers CagA into the cytosol of gastric epithelial cells through a rigid needle structure covered by CagY, a VirB10-homologous protein and CagT, a VirB7-homologous protein, at the base (Covacci \& Rappuoli, 2000; Rohde et al., 2003). H. pylori cagA positive strains are associated with higher grades of inflammation and a significantly increased risk of developing gastric cancer (Parsonnet et al., 1997). cagT gene is found at the base of the outgrowing pilus of the type IV secretion system and is supposed to be responsible for binding to a cellular receptor to induce interleukine- 8 secretion and eject CagA (Rohde et al., 2003).

Finally, the duodenal ulcer promoting gene (dupA) was the first putative disease specific marker whose association was described using H. pylori strains obtained in both Asian 
(Japan and Korea) and Western (Colombia) regions (Lu et al., 2005). dupA gene is suggested to be a vir homologue and encompasses the sequences jhp0917 and jhp0918, as described in strain J99. This gene is associated with interleukin-8 induction (Schmidt et al., 2009) and is possibly part of a yet unidentified type IV secretion system (Lu et al., 2005). The original description of dupA reported that its presence was inversely related to mucosal atrophy and gastric cancer (Zhang et al., 2008, Yamaoka, 2008).

$H$. pylori is an universal distribution bacterium which affects more than half of the world population, and is considered an important public health problem. Even though its transmission pathways are not completely clarified (Rothenbacher et al., 1998), infection by H. pylori is usually acquired during childhood and is characterized as being chronic, with greater prevalence in developing countries in all ages (Kodaira et al., 2002).

Colonization with $H$. pylori is not actually a disease but a condition that affects the relative risk of developing various clinical disorders of the upper gastrointestinal tract (Kusters et al., 2006) and, possibly, extradigestive disorders (Gasbarrini et al., 1999; Figura et al., 2010). In the first case, $H$. pylori infection is responsible for the development of chronic gastritis, peptic ulcers, mucosa associated lymphoid tissue (MALT lymphoma) and gastric adenocarcinoma (Ahmed \& Sechi, 2005). Regarding to extradigestive diseases, H. pylori infection has been associated with iron-deficiency anemia (Capurso et al., 2001), idiopathic thrombocytopenic purpura (Pellicano et al., 2009; Arnold et al., 2009), cardiovascular diseases (Franceschi et al., 2009), hepatobiliary diseases (Isaeva et al., 2009; Pirouz et al., 2009) and amongst others.

Especially with regards to gastric cancer, the interest in $H$. pylori as a cause of this illness began after the pioneering discoveries of Marshall and Warren. Prior to the discovery of the organism, it was known that gastric adenocarcinomas typically arose in areas of gastritis. When the relationship between $H$. pylori and chronic gastritis was established, investigators began to take interest in the causal role of the bacterium in gastric cancer (Herrera \& Parsonnet, 2009). Therefore, on the basis of numerous epidemiological studies, H. pylori infection has been shown to be associated with an increased risk of gastric adenocarcinoma development (Parsonnet et al., 1997; Sugiyama \& Asaka, 2004). Evidence that the presence of $H$. pylori increases the risk of developing gastric cancer through atrophy and intestinal metaplasia has also been reported (Asaka et al., 1994; Kuipers, 1995), suggesting that $H$. pylori positive patients developed these conditions in a greater proportion than control subjects. Besides, research conducted in animal models (Zhou et al., 2004) demonstrated that the eradication of the bacteria could reduce the incidence of gastric cancer in mice that developed the disease by inoculation of strains of $H$. pylori and administration of low doses of carcinogenic agents. These findings suggest that eradication of these bacteria during precancerous lesions of the disease significantly can reduce the incidence of gastric cancer also in humans (Sugiyama \& Asaka, 2004). Consequently, in 1994 the International Agency for Research on Cancer, World Health Organization, concluded that H. pylori has a causal link with gastric carcinogenesis and was defined as type I carcinogen, a definite cause of cancer in humans (IARC, 1994).

Gastric cancer continues to be a major global health problem (Malfertheiner et al., 2010) and, despite the decreasing incidence and mortality rates observed worldwide over the last 50 years, it still ranks as a leading cause of cancer-related deaths in many parts of the world (Nardone et al., 2004). As symptoms are often absent or nonspecific in patients with the early stages of the disease, gastric cancer is usually diagnosed in an advanced stage, when curative options are limited. With exceptions in countries that have developed screening 
programs for early diagnoses, most patients reach treatment with cancers already in advanced stages (Hohenberger \& Gretschel, 2003). Consequently, gastric cancer carries a poor prognosis, with an overall five-year survival rate of less than $20 \%$ (Bowles \& Benjamin, 2001).

The vast majority of gastric cancers are adenocarcinomas, which can be prevalently divided into two types, the intestinal and the diffuse (Lauren, 1965), which corresponds, respectively, to the well-differentiated type and to the poorly-differentiated type, in the Japanese classification (Sugiyama \& Asaka, 2004). In contrast to the diffuse type (Figure 1), often associated with familial distribution and developed in the stomach following chronic inflammation, especially in the cardia (Nardone et al., 2004), intestinal type adenocarcinomas (Figure 2) are generally thought to be preceded by a sequence of precursor lesions (Correa, 1975). The basic components of this process are chronic inflammation of the gastric mucosa, which slowly progresses through the premalignant stages of atrophic gastritis, intestinal metaplasia and dysplasia to gastric cancer (Figure 3) (Correa \& Houghton, 2007). In respect to localization in the stomach, premalignant lesions are most frequently localized in the antrum in the transitional zone between the antrum and corpus (de Vries et al., 2007).

Unlike patients with advanced gastric cancer, patients diagnosed in an early stage of the disease present an excellent prognostic, in which a five-year survival rate is more than $90 \%$. This disorder is defined as the adenocarcinoma that is confined to the mucosa or submucosa, irrespective of lymph-node invasion (Everett \& Axon, 1998). Many early gastric cancers are believed to go through a life cycle consisting of ulcerations, followed by healing, then reulceration, and some tumours remain at this early stage for years even without treatment (Everett \& Axon, 1998). Nevertheless, some early tumours rapidly became advanced and it is one of the principal questions concerning gastric carcinogenesis (Figure 4).

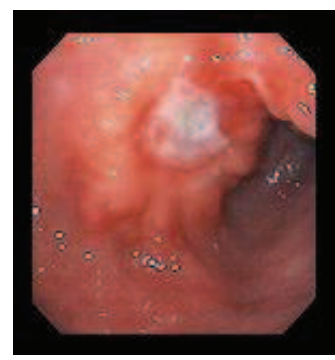

Fig. 1. Diffuse type adenocarcinoma

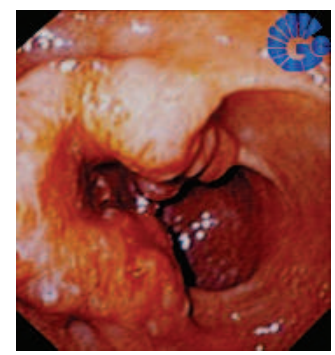

Fig. 2. Intestinal type adenocarcinoma 


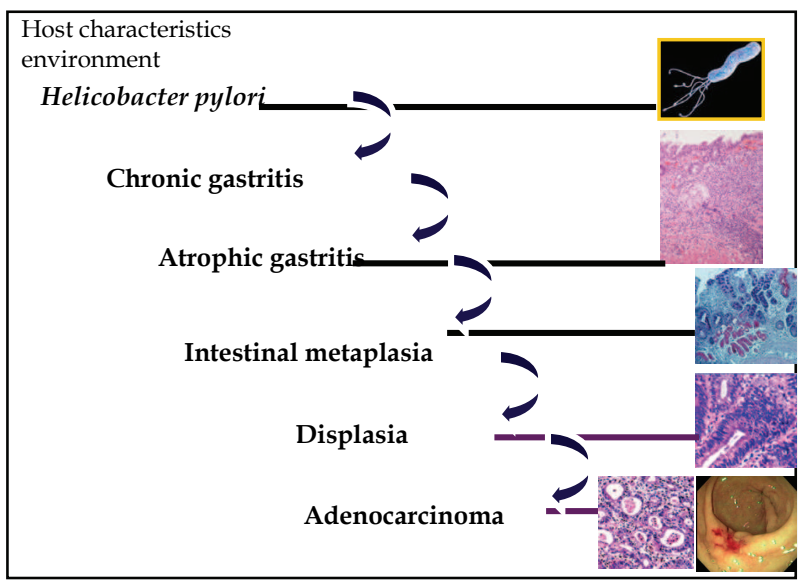

Fig. 3. Sequence of precursor lesions of the intestinal type adenocarcinoma development

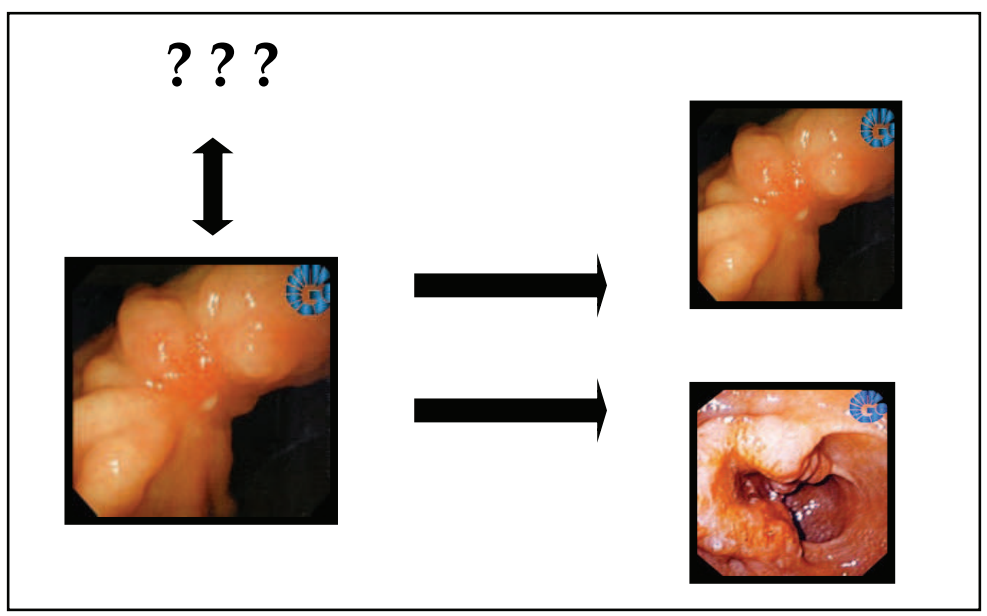

Fig. 4. Early gastric cancer: healing, maintenance or progression.

Have H. pylori virulence factors influenced this alteration? Why any tumour remains at an early stage for years even without treatment, or why they are able to heal by themselves, we do not know. Obviously, gastric carcinogenesis involves the interaction of the etiologic agent (H. pylori), the host characteristics and the external environment (Kabir, 2009), and, in this relationship, it should be considered the different strains of H. pylori and their virulence factors, important keys in the role of gastric carcinogenesis. Consequently, with the aim to try and understand better the mechanism of gastric carcinogenesis, especially concerning about the act of $H$. pylori, in which present studies have identified and analysed possible and essential differences among $H$. pylori strains derived from patients with early and advanced distal intestinal type gastric adenocarcinoma. Molecular biology techniques were 
used in order to amplify genes of this bacterium that act as virulence factors, comparing the results obtained in the two severities of illness.

\section{Clinical samples, methods and results}

\subsection{Clinical samples}

Clinical isolates of $H$. pylori used in this study were obtained from the Laboratory of Pathology of the Centre of Diagnosis of Digestive Diseases, Faculty of Medical Sciences, State University of Campinas (UNICAMP), São Paulo, Brazil. Eighty nine paraffin waxembedded specimens of gastric tissue were analysed from a total of 89 patients: 31 of these were diagnosed with early distal type intestinal gastric adenocarcinoma (group one) and 58 with advanced distal type intestinal gastric adenocarcinoma (group two). The mean ages of group one were 61.0 years, with 20 male cases $(64.5 \%)$ and 11 female cases $(35.5 \%)$. For group two the mean ages was 64.5 years, with 40 male cases $(69.0 \%)$ and 18 female cases (31.0\%). All the gastric tissue samples were obtained from endoscopic biopsy and had positive results for $H$. pylori by histological analysis. Samples from gastric tissues obtained by endoscopic biopsy of patients with chronic gastritis and peptic ulcers were used as a control for all the reactions performed in this study. Primer pairs were chosen in order to amplify final products with similar length (base pairs) and, with this aim, only for the cagA gene, we used the nested PCR. Finally, all the stages of this study were approved by the Ethics Committee of the Faculty of Medical Sciences, State University of Campinas (UNICAMP).

\subsection{Methods}

\subsubsection{DNA extraction}

Paraffin wax-embedded tissue DNA extraction was performed by carrying out the preextraction treatment of fixed tissues, using xylene and ethanol washes for paraffin removal. Subsequently, successive steps using proteinase K, phenol, chloroform and isoamyl alcohol were carried out, in order to isolate and purify the DNA (Goelz et al., 1985). Quantification of the extracted DNA and polymerase chain reaction (PCR) for human betaglobin gene (Saiki et al., 1988) were carried out in order to guarantee the quality of this research.

\subsubsection{PCR for urease $C$, vacA (regions $s$ and $m$ ), cagA, cagT and dupA (regions jhp0917 and jhp0918) genes}

Primer pairs for all the genes are described in Table 1, as well as the length of the fragments amplified for each reaction: urease C (Lage et al., 1995), vacA s1/s2 (Atherton et al., 1997), vacA m1/m2 (Atherton et al., 1999; Thomazini et al., 2006), cagA (Faundez et al., 2002), cagT (Mattar et al., 2007) and dupA jhp0917 and jhp0918 (Lu et al., 2005). PCR for urease C gene was performed with the aim to identify the bacterium DNA in samples.

After amplification, each PCR product was submitted to eletrophoresis on a $2 \%$ agarose gel stained by ethidium bromide with a $0.5 \mathrm{X}$ tris-acetate-EDTA buffer. A 100-bp ladder was used as standard.

Then, for each specific reaction, after being tested positive for urease $\mathrm{C}$ gene, products obtained were classified in vacA $\mathrm{s} 1 \mathrm{~m} 1, \mathrm{~s} 2 \mathrm{~m} 1, \mathrm{~s} 1 \mathrm{~m} 2$ or $\mathrm{s} 2 \mathrm{~m} 2$, cagA positive or negative, cagT positive or negative, dupA jhp0917 positive or negative and dupA jhp0918 positive or negative; dupA gene was considered positive when its two regions were positive simultaneously. 
Virulence Factors of Helicobacter pylori and Their Relationship

\begin{tabular}{|c|c|c|c|}
\hline Gene & Strand & Primer sequence $\left(5^{\prime}-3^{\prime}\right)$ & Length (bp) \\
\hline \multirow[t]{2}{*}{ Betaglobin } & + & ACACAACTGTGTTCACTAGC & 110 \\
\hline & - & CAACTTCATCCACGTTTCACC & \\
\hline \multirow[t]{2}{*}{ Urease C } & + & AAGCTTTTAGGGGTGTTAGGGGTTT & 294 \\
\hline & - & AAGCTTACTTTCTAACACTAACGC & \\
\hline \multirow[t]{2}{*}{$\operatorname{vacA} \mathrm{s}(\mathrm{s} 1 / \mathrm{s} 2)$} & + & ATGGAAATACAACAAACACAC & S1,259; s2: 286 \\
\hline & - & CTGCTTGAATGCGCCAAAC & \\
\hline \multirow[t]{2}{*}{ vacA m1 } & + & GGTCAAAATGCGGTCATGG & 290 \\
\hline & - & CCATTGGTACCTGTAGAAAC & \\
\hline \multirow[t]{2}{*}{ vacA m2 } & + & ATGCTTTAATATCGTTGAGA & 198 \\
\hline & - & GAA CAT GTT TTA GTG AAA GC & \\
\hline \multirow[t]{2}{*}{ cagA (1st PCR) } & + & $\begin{array}{l}\text { GATAACAGGCAAGCTTTTGAGAGGG } \\
\text { A }\end{array}$ & 393 \\
\hline & - & CCATGAATTTTTGATCCGTTCGG & \\
\hline \multirow[t]{2}{*}{ cagA (nested) } & + & GATAACAGGCAAGCTTTTGAGG & 349 \\
\hline & - & CTGCAAAAGATTGTTTGGCAGA & \\
\hline \multirow[t]{2}{*}{$\operatorname{cagT}$} & + & CCATGTTTATACGCCTGTGT & 301 \\
\hline & - & CATCACCACACCCTTTTGAT & \\
\hline \multirow[t]{2}{*}{ dupA (jhp0917) } & + & TGGTTTCTACTGACAGAGCGC & 307 \\
\hline & - & AACACGCTGACAGGACAATCTCCC & \\
\hline \multirow[t]{2}{*}{ dupA (jhp0918) } & + & CCTATATCGCTAACGCGCGCTC & 276 \\
\hline & - & AAGCTGAAGCGTTTGTAACG & \\
\hline
\end{tabular}

Table 1. Sequence of synthetic oligonucleotide primers used to characterization of H. pylori strains

\subsubsection{Statistical analysis}

After all amplification reactions, the results were analysed by a chi-square test at the Statistical Service of the Faculty of Medical Sciences at UNICAMP. Results were then related to the diseases in study, observing possible differences among $H$. pylori strains encountered in early and in advanced distal type intestinal gastric adenocarcinoma. Values of $\mathrm{p}<0.05$ were considered to be statistically significant. The results as a whole, after comparison between the two groups, were depicted. Odd ratios with a confidence interval of $95 \%$ were also observed. Tables with absolute frequencies (n) and percentages (\%) were made in order to determine genotypes combinations. Then, Exact Fischer's Test was used in order to compare the genotypes combinations between early and advanced gastric cancer. Values of $\mathrm{p}<0.05$ were considered to be statistically significant.

\subsection{Results}

PCR for the urease $\mathrm{C}$ gene of $H$. pylori was positive in all 89 samples, identifying the bacterium DNA (Table 2; Figure 5). For the vacA gene, with regard to region s, of 31 samples from patients with early gastric cancer, $71.0 \%$ (22 cases) were s1 and $29.0 \%$ (9 cases) s2. Fifty eight samples from patients with advanced gastric cancer, $70.7 \%$ (41 cases) were s1 and $29.3 \%$ (17 cases) s2 ( $p=0.978$ ) (Table 2; Figure 6). In conclusion, $63(70.8 \%)$ samples were diagnosed with vacA subtype s1 and 26 (29.2\%) samples were with subtype vacA s2. Related to the vacA gene subunit $\mathrm{m}$, no positive results were observed for the vacA gene subunit m2. From all 89 samples, 31 patients with early gastric cancer and 58 patients with 
advanced gastric cancer were $\mathrm{m} 1$ positive (Table 2; Figure 7). Following this analysis, samples were classified into s1m1 or s2m1. For patients with early gastric cancer, $71.0 \%$ (22 cases) were $\mathrm{s} 1 \mathrm{~m} 1$ and $29.0 \%$ (9 cases) were s2m1. From 58 samples of patients with advanced gastric cancer, $70.7 \%$ (41 cases) were s1m1 and $29.3 \%$ (17 cases) s $2 \mathrm{~m} 1$ (table 3). Results were not statistically significant $(\mathrm{p}=0.978)$. In conclusion, $63(70.8 \%)$ samples were vacA s1m1 and 26 (29.2\%) were vacA s2m1 (Table 2).

Analyzing the cagA gene, from patients with early gastric cancer, 61.3\% (19 cases) were positive and from patients with advanced gastric cancer, $82.8 \%$ (48 cases) were positive ( $\mathrm{p}=$ 0.025), with an odds ratio of 3.032, 95\% confidence interval (1.123-8.185) (Table 2; Figure 8). In the group as a whole, there were 67 positive cases $(75.3 \%)$ for the cagA gene. On the other hand, analyzing the cagT gene of $H$. pylori, from patients with early gastric adenocarcinoma $54.8 \%$ (17 cases) were positive and in patients with advanced gastric adenocarcinoma, $65.5 \%$ (38 cases) were positive $(\mathrm{p}=0.323)$ (Table 2; Figure 9$)$. In the group there were 55 positive cases $(61.8 \%)$ for the cagT gene.

Results of dupA jhp0917 in patients with early gastric cancer, 35.5\% (11 cases) presented positive results and in patients with advanced gastric cancer, 39.7\% (23 cases) presented positive $(\mathrm{p}=0.700)$ (Table 2; Figure 10). In the group as a whole, there were 34 positive cases (38.2\%) and 55 negative cases (61.8\%) for jhp0917. Tests of dupA jhp0918 in patients with early gastric cancer, $51.6 \%$ (16 cases) had positive results and In patients with advanced gastric cancer, $55.2 \%$ (32 cases) were positive $(\mathrm{p}=0.748)$ (Table 2; Figure 11). The $\mathrm{p}$ value obtained was 0.748 , which was not statistically significant. In the group there were 48 cases $(53.9 \%)$ that were positive for dupA jhp0918 gene and 41 cases $(46.1 \%)$ that were negative.

\begin{tabular}{lcccc}
\hline Classification & $\begin{array}{c}\text { Early gastric } \\
\text { cancer }\end{array}$ & $\begin{array}{c}\text { Advanced gastric } \\
\text { cancer }\end{array}$ & Total & p value \\
\hline urease C & $31(100.0 \%)$ & $58(100.0 \%)$ & $89(100.0 \%)$ & \\
\hline s1 & $22(71.0 \%)$ & $41(70.7 \%)$ & $63(70.8 \%)$ & \\
s2 & $9(29.0 \%)$ & $17(29.3 \%)$ & $26(29.2 \%)$ & $\mathrm{p}=0.978$ \\
\hline $\mathrm{m} 1$ & $31(100.0 \%)$ & $58(100.0 \%)$ & $89(100.0 \%)$ & \\
$\mathrm{m} 2$ & $0(0.0 \%)$ & $0(0.0 \%)$ & $0(0.0 \%)$ & \\
s1m1 & $22(71.0 \%)$ & $41(70.7 \%)$ & $63(70.8 \%)$ & \\
s2m1 & $9(29.0 \%)$ & $17(29.3 \%)$ & $26(29.2 \%)$ & $\mathrm{p}=0.978$ \\
\hline cagA positive & $19(61.3 \%)$ & $48(82.8 \%)$ & $67(75.3 \%)$ & \\
cagA negative & $12(38.7 \%)$ & $10(17.2 \%)$ & $22(24.7 \%)$ & $\mathrm{p}=0.025^{*}$ \\
\hline cagT positive & $17(54.8 \%)$ & $38(65.5 \%)$ & $55(61.8 \%)$ & \\
cagT negative & $14(45.2 \%)$ & $20(34.5 \%)$ & $34(38.2 \%)$ & $\mathrm{p}=0.323$ \\
\hline dupA jhp0917 positive & $11(35.5 \%)$ & $23(39.7 \%)$ & $34(38.2 \%)$ & \\
dupA jhp0917 negative & $20(64.5 \%)$ & $35(60.3 \%)$ & $55(61.8 \%)$ & $\mathrm{P}=0.700$ \\
\hline dupA jhp0918 positive & $16(51.6 \%)$ & $32(55.2 \%)$ & $48(53.9 \%)$ & \\
dupA jhp0918 negative & $15(48.4 \%)$ & $26(44.8 \%)$ & $41(46.1 \%)$ & $\mathrm{P}=0.748$ \\
\hline Total & $31(100.0 \%)$ & $58(100.0 \%)$ & $89(100.0 \%)$ & \\
\hline
\end{tabular}

* cagA gene $(\mathrm{p}=0.025), \mathrm{OR}=3.032(95 \% \mathrm{CI}, 1.123-8.185)$

Table 2. General results obtained after reactions for urease C, vacA (s/m), cagA, cagT and dupA jhp0917 and jhp0918 genes of Helicobacter pylori 


\section{L $\quad$ C $+0102 \quad 03 \quad$ C-}

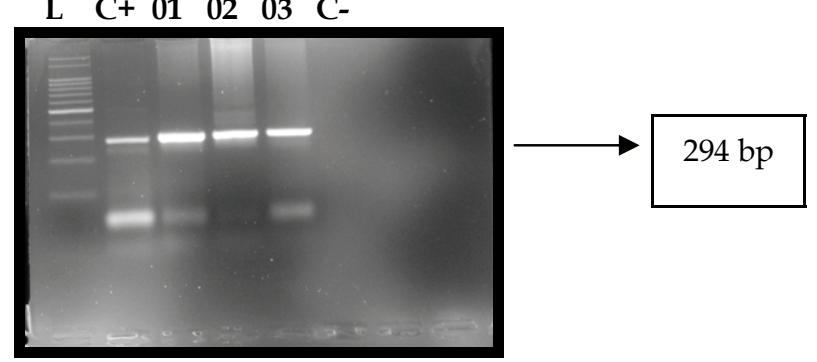

Fig. 5. Amplification of the urease C gene of H. pylori (294 bp); L, ladder $100 \mathrm{bp}$; C+, positive control; 01 to 03 , positive samples; C-, negative control.

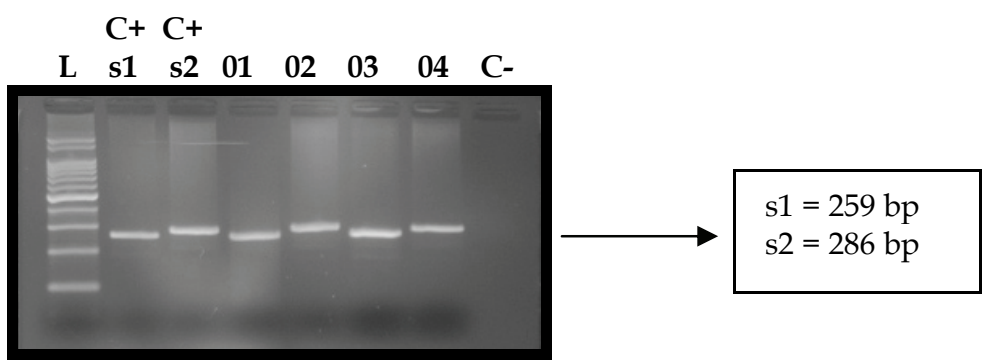

Fig. 6. Amplification of the vacA region s gene of $H$. pylori (s1, $259 \mathrm{bp} ; \mathrm{s} 2,286 \mathrm{bp}$ ); L, ladder $100 \mathrm{bp}$; C+s1, positive control for vacA s1; C+s2, positive control for vacA s2; 01 and 03, positive samples for s1; 02 and 04 , positive samples for s2; C-, negative control.

C+

L m1 $010203 \quad 04 \quad C-$

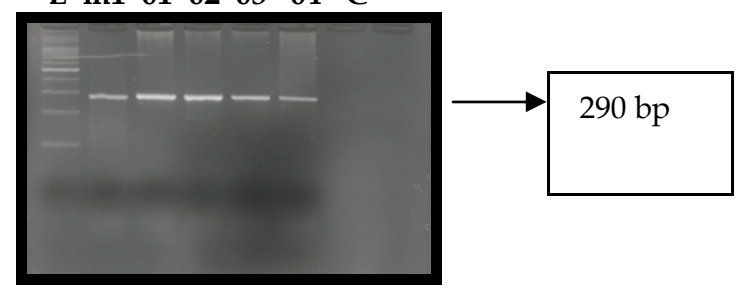

Fig. 7. Amplification of the vacA m1 region of H. pylori (290 bp). L, ladder $100 \mathrm{bp}$; $\mathrm{C}+\mathrm{m} 1$, positive control for vacA m1; 01 to 04 , positive samples; C-, negative control. 


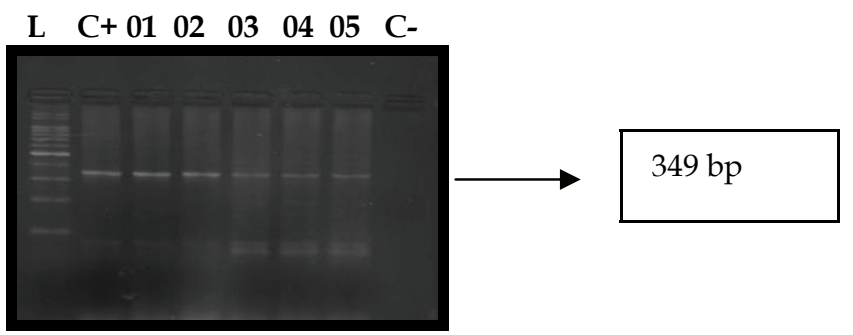

Fig. 8. Amplification of cagA gene of H. pylori (349 bp). L, ladder $100 \mathrm{bp}$; C+, positive control; 01 to 05 , positive samples; $\mathrm{C}-$, negative control.

$\begin{array}{lllllll}\text { L } & \text { C }+0102 & 03 & 04 & 05 & \text { C- }\end{array}$

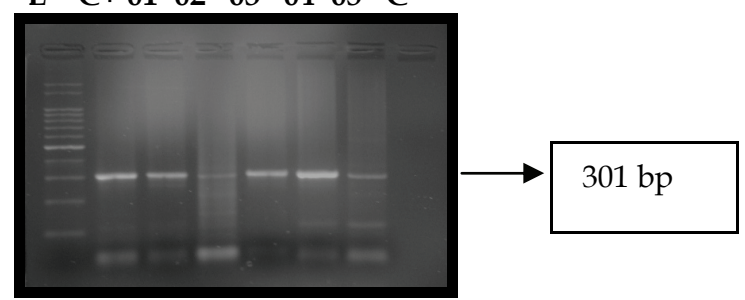

Fig. 9. Amplification of cagT gene of H. pylori (301 bp). L, ladder $100 \mathrm{bp}$; C+, positive control; 01 to 05 , positive samples; C-, negative control.

\section{C +01020304 C-}

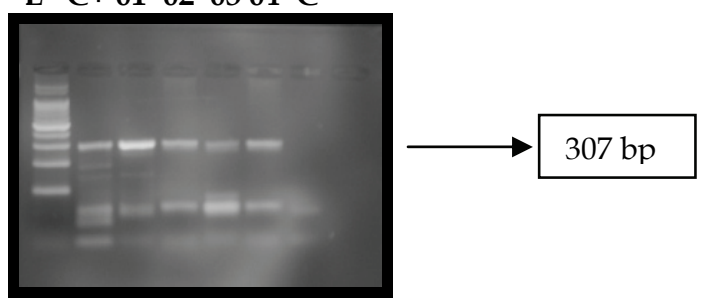

Fig. 10. Amplification of dupA jhp0917 gene of H. pylori (307 bp). L, ladder 100 bp; C+, positive control; 01 to 04 , positive samples; C-, negative control. 


\section{C $+010203 \mathrm{C}-$}

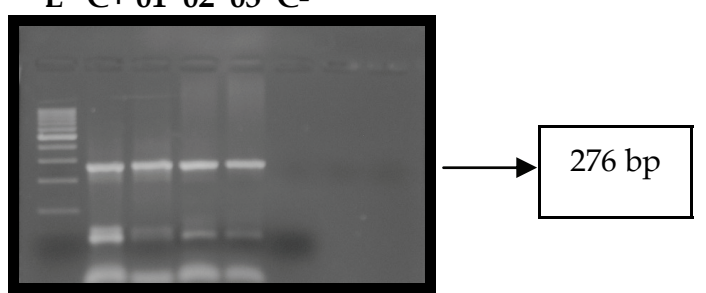

Fig. 11. Amplification of dupA jhp0918 gene of H. pylori (276 bp). L, ladder 100 bp; C+, positive control; 01 to 03 , positive samples; C-, negative control.

After this analysis, tables with absolute frequencies (n) and percentages (\%) were made in order to compare the genotypes combinations. vacA s1m1, cagA positive, cagT positive and dupA negative were, individually, the most frequent genotypes (Table 3 ). In order to specify better the results obtained, the dupA gene was considered positive when its two continuous regions (jhp0917 and jhp0918) were positive simultaneously. So, the combinations of genotypes were made and then compared between the two groups of patients, with early and advanced gastric cancer (Tables 4 and 5, respectively). The most prevalent genotype for all the samples, in both groups of patients, was vacA s1m1, cagA positive, cagT positive and dupA negative. The percentage was 29.21\%. About the comparison of genotypes combinations between the two groups of samples, there was not a significant difference $(p=0.116)$.

\begin{tabular}{|l|c|c|c|}
\hline \multicolumn{2}{|l|}{ Genomic region } & $\begin{array}{c}\text { Frequence } \\
\text { (n) }\end{array}$ & $\begin{array}{c}\text { Percentage } \\
(\%)\end{array}$ \\
\hline \multirow{2}{*}{ vacA s/m gene } & s1m1 & 63 & 70.79 \\
\cline { 2 - 4 } & s2m1 & 26 & 29.21 \\
\hline \multirow{2}{*}{ cagA gene } & positive & 67 & 75.28 \\
\cline { 2 - 4 } & negative & 22 & 24.72 \\
\hline \multirow{2}{*}{ cagT gene } & positive & 55 & 61.80 \\
\cline { 2 - 4 } & negative & 34 & 38.20 \\
\hline \multirow{2}{*}{ dupA jhp0917 gene } & positive & 34 & 38.20 \\
\cline { 2 - 4 } & negative & 55 & 61.80 \\
\hline \multirow{2}{*}{ dupA jhp0918 gene } & positive & 48 & 53.93 \\
\cline { 2 - 4 } & negative & 41 & 46.07 \\
\hline \multirow{2}{*}{ dupA jhp0917/0918 gene } & positive & 28 & 31.46 \\
\cline { 2 - 4 } & negative & 61 & 68.54 \\
\hline
\end{tabular}

Table 3. Descriptive analysis of genomic regions of H. pylori 


\begin{tabular}{|l|c|c|}
\hline $\begin{array}{l}\text { Genotypes combinations: } \\
\text { vacA s/m, cagA, cagT, dupA (jhp0917/0918) }\end{array}$ & $\begin{array}{c}\text { Frequency } \\
(\mathrm{n})\end{array}$ & $\begin{array}{c}\text { Percentage } \\
(\%)\end{array}$ \\
\hline s1m1 neg neg neg & 8 & 8.99 \\
\hline s1m1 neg neg pos & 1 & 1.12 \\
\hline s2m1 neg neg neg & 3 & 3.37 \\
\hline s2m1 neg neg pos & 2 & 2.25 \\
\hline s1m1 neg pos neg & 3 & 3.37 \\
\hline s1m1 neg pos pos & 1 & 1.12 \\
\hline s2m1 neg pos neg & 2 & 2.25 \\
\hline s2m1 neg pos pos & 2 & 2.25 \\
\hline s1m1 pos neg neg & 9 & 10.11 \\
\hline s1m1 pos neg pos & 6 & 6.74 \\
\hline s2m1 pos neg neg & 4 & 4.49 \\
\hline s2m1 pos neg pos & 1 & 1.12 \\
\hline s1m1 pos pos neg & 26 & 29.21 \\
\hline s1m1 pos pos pos & 9 & 10.11 \\
\hline s2m1 pos pos neg & 6 & 6.74 \\
\hline s2m1 pos pos pos & 6 & 6.74 \\
\hline
\end{tabular}

Table 4. Genotype combinations, according to the results obtained for vacA s/m, cagA, cagT and dupA (jhp0917/0918) genes of H. pylori

\begin{tabular}{|c|c|c|c|}
\hline $\begin{array}{l}\text { Genotype combinations: } \\
\text { vacA s/m, cagA, cagT, dupA (jhp0917/0918) }\end{array}$ & $\begin{array}{l}\text { Early gastric } \\
\text { câncer }\end{array}$ & $\begin{array}{l}\text { Advanced } \\
\text { gastric cancer }\end{array}$ & Total \\
\hline s1m1 neg neg neg & $\begin{array}{c}4 \\
12.90\end{array}$ & $\begin{array}{c}4 \\
6.90\end{array}$ & 8 \\
\hline s1m1 neg neg pos & $\begin{array}{c}1 \\
3.23 \\
\end{array}$ & $\begin{array}{c}0 \\
0.00\end{array}$ & 1 \\
\hline s2m1 neg neg neg & $\begin{array}{c}1 \\
3.23\end{array}$ & $\begin{array}{c}2 \\
3.45\end{array}$ & 3 \\
\hline s2m1 neg neg pos & $\begin{array}{c}0 \\
0.00\end{array}$ & $\begin{array}{c}2 \\
3.45\end{array}$ & 2 \\
\hline s1m1 neg pos neg & $\begin{array}{c}2 \\
6.45\end{array}$ & $\begin{array}{c}1 \\
1.72\end{array}$ & 3 \\
\hline s1m1 neg pos pos & $\begin{array}{c}1 \\
3.23 \\
\end{array}$ & $\begin{array}{c}0 \\
0.00\end{array}$ & 1 \\
\hline s2m1 neg pos neg & $\begin{array}{c}2 \\
6.45\end{array}$ & $\begin{array}{c}0 \\
0.00 \\
\end{array}$ & 2 \\
\hline s2m1 neg pos pos & $\begin{array}{c}1 \\
3.23\end{array}$ & $\begin{array}{c}1 \\
1.72\end{array}$ & 2 \\
\hline s1m1 pos neg neg & $\begin{array}{c}3 \\
9.68\end{array}$ & $\begin{array}{c}6 \\
10.34\end{array}$ & 9 \\
\hline s1m1 pos neg pos & $\begin{array}{c}2 \\
6.45\end{array}$ & $\begin{array}{c}4 \\
6.90 \\
\end{array}$ & 6 \\
\hline s2m1 pos neg neg & $\begin{array}{c}2 \\
6.45\end{array}$ & $\begin{array}{c}2 \\
3.45\end{array}$ & 4 \\
\hline
\end{tabular}




\begin{tabular}{|c|c|c|c|}
\hline $\begin{array}{l}\text { Genotype combinations: } \\
\text { vacA s/m, cagA, cagT, dupA (jhp0917/0918) }\end{array}$ & $\begin{array}{l}\text { Early gastric } \\
\text { câncer }\end{array}$ & $\begin{array}{l}\text { Advanced } \\
\text { gastric cancer }\end{array}$ & Total \\
\hline s2m1 pos neg pos & $\begin{array}{c}1 \\
3.23 \\
\end{array}$ & $\begin{array}{c}0 \\
0.00\end{array}$ & 1 \\
\hline s1m1 pos pos neg & $\begin{array}{c}5 \\
16.13 \\
\end{array}$ & $\begin{array}{c}21 \\
36.21 \\
\end{array}$ & 26 \\
\hline s1m1 pos pos pos & $\begin{array}{c}4 \\
12.90\end{array}$ & $\begin{array}{c}5 \\
8.62 \\
\end{array}$ & 9 \\
\hline s2m1 pos pos neg & $\begin{array}{c}2 \\
6.45 \\
\end{array}$ & $\begin{array}{c}4 \\
6.90 \\
\end{array}$ & 6 \\
\hline s2m1 pos pos pos & $\begin{array}{c}0 \\
0.00 \\
\end{array}$ & $\begin{array}{c}6 \\
10.34 \\
\end{array}$ & 6 \\
\hline Total & 31 & 58 & 89 \\
\hline
\end{tabular}

$\mathrm{p}=0.116$

Table 5. Comparison of genotypes combinations between early and advanced gastric cancer.

\section{Conclusions}

The understanding of gastric carcinogenesis has advanced considerably in recent decades, especially as regards to the role of Helicobacter pylori in the progression of chronic gastritis in precancerous lesions and cancer (de Vries et al., 2007). The risk of development of gastric cancer is also related to genetic characteristics of the host and environmental factors, which, associated with specific bacterial strain characteristics, influence the severity of the chronic inflammatory response (Peek et al., 1999). Thus, although infection with H. pylori almost always results in chronic active gastritis, many infected patients do not develop any complication, even those not showing clinical symptoms of infection (Blaser \& Atherton, 2004). This leads to the conclusion that some strains are more virulent than others (Kusters et al., 2006), expressing, in different manners, specific bacterial products.

In the present study, we compared the H. pylori strains obtained from patients with early and advanced distal type intestinal gastric adenocarcinoma with the aim to identify possible differences among strains present in one or other case, using the polymerase chain reaction (PCR) for several bacterial genome regions. The primary detection of $H$. pylori in the samples was performed using the urease $C$ region, present in all strains. After this, PCR was used for amplifying two genes from the cagPAI ( $\operatorname{cagA}$ and $\operatorname{cagT}$ ), the vacA gene (regions $\mathrm{s}$ and $\mathrm{m}$ ) and the dupA gene (jhp0917/0918).

Strains with an s1-type signalling-sequence allele produce functional VacA toxin, whereas those with an s2-type signalling sequence have little cytotoxic activity (Peek \& Blaser, 2002). Moreover, mosaic s1m1 strains are more toxic than $\mathrm{s} 1 \mathrm{~m} 2$ strains and are associated with more severe forms of gastritis, atrophy and intestinal metaplasia (Björkholm et al., 2003). The presence of $\mathrm{s} 1 \mathrm{~m} 1 \mathrm{vacA}$ alleles is also strongly correlated with the expression of the cagPAI (Covacci et al., 1993; Tummuru et al., 1993). Although located on a different loci of the H. pylori chromosome, cagA is strongly linked with VacA cytotoxic activity (Hocker \& Hohenberger, 2003) and strains expressing the combination of these alleles and cag-PAI show enhanced epithelial cell injury (Ghiara et al., 1995). In our study, for patients with advanced gastric cancer, we found prevalent cagA positive $(82.8 \%)$ and vacA s1m1 $(70.7 \%)$ strains, corroborating the results of other studies (Miehlke et al., 2000; Leanza et al., 2004), 
and demonstrating that this combination can result in more virulent strains. These results are also similar to those obtained in China (Qiao et al., 2003), where H. pylori strains were cagA positive in $95 \%$ of samples in the gastric cancer group and the expression of type s1 vacA was more than type s2. Nevertheless, with respect to type $m$, the expression of type $\mathrm{m} 1$ was equal to type $\mathrm{m} 2$, even in the gastric cancer group. In our study we did not find a positive result for $\mathrm{m} 2$.

With regards to early gastric cancer patients, unless we found strains with the same characteristics to those of advanced gastric cancer, some samples (cagA positive for $61.3 \%$ of samples and vacA $\mathrm{s} 1 \mathrm{~m} 1$ for $71.0 \%$ of samples), were positive for cagA and vacA s2m1 (29.0\%), which may contribute for the maintenance of the early stage of disease. In addition, one possible explanation would be that the strains found in early lesions, in relation to the cagA gene, could be different which respects to their EPYIA motifs (polymorfisms of the cagA gene) (Nguyen et al., 2009; Truong et al., 2009), leading to the maintenance of early stage disease, without its progression to advanced lesions.

As regards to the cagA gene, in an isolate analysis, our results were similar to those of in which strains cagA positive were related to the development of gastric cancer. cagA positive strains tend to be more virulent and induce higher levels of expression of cytokines such as interleukin $1 \mathrm{~b}$ and 8 (El-Omar et al., 2000). Some studies have shown that patients with strains that express CagA are three times more likely to develop gastric cancer [Parsonnet et al., 1997; Huang et al., 2003) than those infected with cagA negative strains (Husson et al., 1995; Yamaoka et al., 1999). In the present study the same characteristics were observed and patients infected with cagA positive strains demonstrated a high risk of advanced gastric cancer development $(\mathrm{OR}=3.032,95 \% \mathrm{CI})$. Besides, studies conducted in Western countries (Crabtree et al., 1994; Blaser et al., 1995) and in Asian countries (Mizushima et al., 2001) reported that most patients with gastric cancer are infected with $H$. pylori cagA positive strains.

Like the cagA gene, the cagT also belongs to the cag pathogenicity island and it is assumed that it is related to the type IV secretion system, responsible for binding to cell receptors and inducing the release of interleukin- 8 and also by ejecting the CagA protein (Rohde et al., 2003). The cagT gene has been linked to the development of peptic ulcer, and strains with the absence of this gene were generally related to chronic gastritis (Mattar et al., 2007). In this study, values were not found to be statistically significant between the two studied groups $(\mathrm{p}=0.323)$. However, the cagT gene was found, in the group as a whole, in $61.8 \%$ of the samples, which reflects a significant result, showing that this gene, like cagA, or acting together with cagA, may be related to gastric cancer development.

Finally, for the dupA gene, which was originally considered a marker for duodenal ulcer disease and a protective factor against gastric cancer in strains isolated from Japan, Korea and Colombia (Lu et al., 2005), we did not find any statistically significant difference between the two studied groups. Thus, although the dupA gene can not be considered as a marker for duodenal ulcer disease, the presence of this gene was found in few samples of patients with gastric cancer, suggesting that it is not an important gene for the development of this disease, by itself. Conversely, dupA genotyping of samples obtained from four populations (Argent et al., 2008), from Belgium, South Africa, China and the United States of America, showed no association of this gene with duodenal ulcer, but suggested an association with gastric cancer. Another study carried out in Brazilian patients (Gomes et al., 2008) also did not find any association between dupA and either of the two diseases. Finally, in India, a study demonstrated a significant association of dupA gene with duodenal ulcer 
disease in the population (Arachchi et al., 2007). These different results demonstrate that further studies are required to elucidate the roles of dupA gene in the development of gastric diseases.

There are a number of studies that have investigated the virulence factors of $H$. pylori strains, but a gene marker for gastric cancer disease has not yet been found. Our study has demonstrated an interaction between some virulence factors found in gastric tissue samples obtained by early and advanced distal type intestinal gastric adenocarcinoma and a significant statistically value for cagA gene, which is more present in patients with advanced cancer. In the group gastric cancer as a whole, we found a prevalence of cagA positive, cagT positive, vacA s1m1 strains genotypes and a low number of dupA positive samples. Between the two groups, there were no statistically differences about the most prevalent combination of genotypes. In conclusion, the identification of a disease specific $H$. pylori virulence factor could be useful in clinical practice, helping to identify patients infected with strains that are able to develop a serious disease, such as gastric cancer.

\section{Acknowledgment}

The authors thank the "Coordenação de Aperfeiçoamento de Pessoal de Nível Superior" (CAPES) and the "Fundação de Amparo à Pesquisa do Estado de São Paulo" (FAPESP) for their financial support; and Centre of Diagnosis of Digestive Diseases, State University of Campinas, for the concession of the use of figures utilized here.

\section{References}

Ahmed, N. \& Sechi, L.A. (2005). Helicobacter pylori and gastroduodenal pathology: New threats of the old friend. Annals of Clinical Microbiology and Antimicrobials, Vol.4, (January 2005), pp. 1-10, ISSN 1476-0711.

Akopyanz, N.; Bukanov, N.O.; Westblom, T.U; Kresovich, S. \& Berg, D.E. (1992). DNA diversity among clinical isolates of Helicobacter pylori detected by PCR-based RAPD fingerprinting. Nucleic Acids Research, Vol.20, No.19, (October 1992), pp. 5137-5142, ISSN 1362-4962.

Alm, R.A.; Ling, L.S.; Moir, D.T.; King, B.L.; Brown, E.D.; Doig, P.C.; Smith, D.R.; Noonan, B.; Guild, B.C.; deJonge, B.L.; Carmel, G.; Tummino, P.J.; Caruso, A.; UriaNickelsen, M.; Mills, D.M.; Ives, C.; Gibson, R.; Merberg, D.; Mills, S.D.; Jiang, Q.; Taylor, D.E.; Vovis, G.F. \& Trust, T.J. (1999). Genomic-sequence comparison of two unrelated isolates of the human gastric pathogen Helicobacter pylori. Nature, Vol.397, No.6715, (January 1999), pp. 176-180, ISSN 0028-0836.

Arachich, H.S.; Kalra, V.; Lal, B.; Bhatia, V.; Baba, C.S.; Chakravarthy, S.; Rohatgi, S., Sarma, P.M.; Mishra, V.; Das, B. \& Ahula, V. (2007). Prevalence of duodenal-ulcer promoting gene (dupA) of Helicobacter pylori in patients with duodenal ulcer in North Indian population. Helicobacter, Vol.12, No.6, (December 2007), pp. 591-597, ISSN 1523-5378.

Argent, R.H.; Thomas, R.J.; Letley, D.P.; Rittig, M.G.; Hardie, K.R. \& Atherton, J.C. (2008). Functional association between the Helicobacter pylori virulence factors VacA and CagA. Journal of Medical Microbiology, Vol.57, No.2, (February 2008), pp. 145-150, ISSN 1473-5644. 
Arnold, D.M.; Bernotas, A.; Nazi, I.; Stasi, R.; Kuwana, M.; Liu, Y.; Kelton, J.G. \& Crowther, M.A. (2009). Platelet count response to H. pylori treatment in patients with immune thrombocytopenic purpura with and without $H$. pylori infection: a systematic review. Haematologica, Vol.94; No.6, (June 2009), pp. 850-856, ISSN 1592-8721.

Asaka, M.; Kimura, T.; Kato, M.; Kudo, M.; Miki, K.; Ogoshi, K.; Kato, T.; Tatsuta, M. \& Graham, D.Y. (1994). Possible role of Helicobacter pylori infection in early gastric cancer development. Cancer, Vol.73, No.11, (June 1994), pp. 2691-2694, ISSN 10970142.

Atherton, J.C.; Cao, P.; Peek Jr, R.M.; Tummuru, M.K.; Blaser, M.J. \& Cover, T.L. (1995). Mosaicism in vacuolating cytotoxin alleles of Helicobacter pylori. Association of specific vacA types with cytotoxin production and peptic ulceration. The Journal of Biological Chemistry, Vol.270, No.30, (July 1995), pp. 1771-1777, ISSN 1083-351X.

Atherton, J.C.; Peek, R.M.; Tham, K.T.; Cover, T.L.\& Blaser, M.J. (1997). Clinical and pathological importance of heterogenicity in vacA, the vacuolating cytotoxin gene of Helicobacter pylori. Gastroenterology, Vol.112, No.1, (January 1997), pp. 92-97, ISSN 0016-5085.

Atherton, J.C.; Cover, T.L.; Twells, R.J.; Morales, M.R.; Hawkey, C.J. \& Blaser, M.J. (1997). Simple and accurate PCR-based system for typing vacuolating cytotoxin alleles of Helicobacter pylori. Journal of Clinical Microbiology, Vol.37, No.9, (September 1999), pp. 2979-2982, ISSN 1098-660X.

Baltrus, D.A; Amieva, M.R.; Covacci, A; Lowe, T.M.; Merrell, D.S; Ottemann, K.M.; Stein, M.; Salama, N.R. \& Guillemin, K. (2009). The complete genome sequence of Helicobacter pylori strain G27. Journal of Bacteriology, Vol.191, No.1, (January 2009), pp. 447-448, ISSN 0021-9193.

Björkholm, B.; Falk, P.; Engstrand, L; \& Nyrén, O. (2003). Helicobacter pylori: resurrection of the cancer link. Journal of Internal Medicine, Vol. 253, No.2, (February 2003), pp. 102119, ISSN 0954-6820.

Blaser, M.J.; Perez-Perez, G.I.; Kleanthous, H.; Cover, T.L.; Peek, R.M.; Chyou, P.H.; Stemmermann, G.N. \& Nomura, A. (1995). Infection with Helicobacter pylori strains possessing cagA is associated with an increased risk of developing adenocarcinoma of the stomach. Cancer Research, Vol.55, No.10, (May 1995), pp. 2111-2115, ISSN 1538-7445.

Blaser, M.J. \& Atherton, J.C. (2004). Helicobacter pylori persistence: biology and disease. The Journal of Clinical Investigation, Vol.113, No.3, (February 2004), pp. 321-333, ISSN 0021-9738.

Bowles, M.J. \& Benjamin, I.C. (2001) ABC of the upper gastrointestinal tract. Cancer of the stomach and pancreas. BMJ, Vol.323, No.7326, (December 2001), pp. 1413-1416, ISSN 1982-9000.

Capurso, G.; Lahner, E.; Marcheggiano, A.; Caruana, P.; Carnuccio, A.; Bordi, C. Delle Fave, G. \& Annibale, B. (2001). Involvement of the corporal mucosa and related changes in gastric acid secretion characterize patients with iron deficiency anemy associated with Helicobacter pylori infection. Alimentary Pharmacology \& Therapeutics, Vol.15, No.11, (November 2001), pp. 1753-1761, ISSN 1365-2036.

Censini, S.; Lange, C.; Xiang, Z.; Crabtree, J.E.; Ghiara, P.; Borodovsky, M.; Rappuoli, R. \& Covacci, A. (1996). Cag, a pathogenicity island of Helicobacter pylori, encodes type Ispecific and disease-associated virulence factors. Proceedings of the National Academy 
of Sciences of the United States of America, Vol.93, No.25, (December 1996), pp. 1464814653, ISSN 1091-6490.

Correa, P.; Haenszel, W.; Cuello, C.; Tannenbaum, S. \& Archer, M. (1975). A model for gastric cancer epidemiology. Lancet, Vol.2, No.7924, (July 1975), pp. 58-60, ISSN 0140-6736.

Correa, P. \& Hughton, J. (2007). Carcinogenesis of Helicobacter pylori. Gastroenterology, Vol.133, No.2, (August 2007), pp. 659-672, ISSN 0016-5085.

Covacci, A.; Censini, S.; Bugnoli, M.; Petracca, R.; Burroni, D.; Macchia, G.; Massone, A.; Papini, E.; Xiang, Z. \& Figura, N. (1993). Molecular characterization of the 128-kDa immunodominant antigen of Helicobacter pylori associated with citotoxicity and duodenal ulcer. Proceedings of the National Academy of Sciences of the United States of America, Vol.90, No.12, (June 1993), pp. 5791-5795, ISSN 1091-6490.

Covacci, A. \& Rappuoli, R. (2000). Tyrosine-phosphorylated bacterial proteins: Trojan horses for the host cell. The Journal of Experimental Medicine, Vol.191, No.4, (February 2000), pp. 587-592, ISSN 1540-9538.

Cover, T.L. \& Blanke, S.R. (2005). Helicobacter pylori VacA, a paradigm for toxin multifunctionality. Nature Reviews. Microbiology, Vol.3, No.4, (April 2005), pp. 320332, ISSN 1740-1526.

Crabtree, J.E; Farmery, S.M.; Lindley, I.J.; Figura, N.; Peichl, P. \& Tompkins, D.S. (1994). CagA/cytotoxic strains of Helicobacter pylori and interleukin-8 in gastric epithelial cell lines. Journal of Clinical Pathology, Vol.47, No.10, (October 1994), pp. 945-950, ISSN 1472-4146.

de Vries, A.C.; Haringsma, J.; \& Kuipers, E.J. (2007). The detection, surveillance and treatment of premalignant gastric lesions related to Helicobacter pylori infection. Helicobacter, Vol.12, No.1, (February 2007), pp. 1-15, ISSN 1523-5378.

Dunn, B.E.; Cohen, H. \& Blaser, M.J. (1997). Helicobacter pylori. Clinical Microbiology Reviews, Vol.10, No.4, (October 1997), pp. 720-741, ISSN 1098-6618.

El-Omar, E.M.; Carrington, M.; Chow, W.H.; McColl, K.E.; Bream, J.H.; Young, H.A.; Herrera, J.; Lissowska, J.; Yuan, C.C.; Rothman, N.; Lanyon, G.; Martin, M.; Fraumeni, J.F. Jr.; \& Rabkin, C.S. (2000). Interleukin-1 polymorphisms associated with increased risk of gastric cancer. Nature, Vol.404, No.6776, (March 2000), pp. 398-402, ISSN 0028-0836.

Everett, S.M. \& Axon, A.T.R. (1998). Early gastric cancer: disease or pseudo-disease? Lancet, Vo.351, No.9112, (May 1998), pp. 1350-1352, ISSN 0140-6736.

Faundez, G.; Troncoso, M. \& Figueroa, G. (2002). cagA and vacA in strains of Helicobacter pylori from ulcer and non-ulcerative dyspepsia patients. BMC Gastroenterology, Vol.2, (September 2002), pp. 20-24, ISSN 1471-230X.

Figura, N.; Guglielmetti, P.; Rossolini, A.; Barberi, A.; Cusi, G.; Musmanno, R.A.; Russi, M. \& Quaranta, S. (1989). Cytotoxin production by Campylobacter pylori strains isolated from patients with peptic ulcers and from patients with chronic gastritis only. Journal of Clinical Microbiology, Vol.27, No.1, (January 1989), pp. 225-226, ISSN 1098$660 \mathrm{X}$.

Figura, N.; Franceschi, F.; Santucci, A.; Bernardini, G.; Gasbarrini, G.; \& Gasbarrini, A. (2010). Extragastric manifestations of Helicobacter pylori infection. Helicobacter, Vol.15, Suppl.1, (January 2010), ISSN 1523-5378. 
Foxall, P.A.; Hu, L.T. \& Mobley, H.L. (1992). Use of polymerase chain reaction-amplified Helicobacter pylori urease structural genes for differentiation of isolates. Journal of Clinical Microbiology, Vol.30, No.3, (March 1992), pp. 739-741, ISSN 1098-660X.

Franceschi, F.; Navarese, E.P.; Mollo, R.; Giupponi, B.; De Marco, G.; Merra, G. Gasbarrini, G. \& Silveri, N.G. (2009). Helicobacter pylori and atherosclerosis. A review of the literature. Recenti Progress in Medicine, Vol.100; No.2, (February 2009), pp. 91-96, ISSN 0034-1193.

Gasbarrini, A.; Franceschi, F.; Armuzzi, A.; Ojetti, V.; Candelli, M.; Sanz Torre, E.S.; De Lorenzo, A.; Anti, M.; Pretolani, S. \& Gasbarrini, G. (1999). Extradigestive manifestations of Helicobacter pylori gastric infection. Gut, Vol.45, Suppl.1, (July 1999), pp. 9-12, ISSN 1468-3288.

Ghiara, P., Marchetti, M.; Blaser, M.J.; Tummuru, M.K.; Cover, T.L.; Segal, E.D.; Tompkins, L.S. \& Rapuolli, R. (1995). Role of the Helicobacter pylori virulence factors vacuolating cytotoxin, CagA, and urease in a mouse model of disease. Infection and immunity, Vol. 63, No.10, (October 1995), pp. 4154-4160, ISSN 1098-5522.

Goelz, S.E; Hamilton, S.R. \& Vogelstein, B. (1985). Purification of DNA from formaldehyde fixed and paraffin embedded human tissue. Biochemical and Biophysical Research Communications, Vol. 130, No.1, (July 1985), pp. 118-126, ISSN 0006-291X.

Gomes, L.I.; Rocha, G.A.; Rocha, A.M.; Soares, T.F.; Oliveira, C.A.; Bittencourt, P.F. \& Queiroz, D.M. (2008). Lack of association between Helicobacter pylori infection with dupA-positive strains and gastroduodenal diseases in Brazilian patients. International Journal of Medical Microbiology, Vol.298, No.3-4, (April 2008), pp. 223230, ISSN 1438-4221.

Goodwin, C.S.R.; McCulloch, R.K.; Armstrong, J.A. \& Wee, S.W. (1987). Unusual cellular fatty acids and distinctive ultrastructure in a new spiral bacterium (Campylobacter pyloridis) from the human gastric mucosa. Journal of Medical Microbiology, Vol.19, (April 1985), pp. 257-267. ISSN 1473-5644.

Goodwin, C.S.R. \& Armstrong, J.A. (1990). Microbiological aspects of Helicobacter pylori (Campylobacter pylori). European Journal of Clinical Microbiology, Vol.9, No.1, (January 1990), pp. 1-13. ISSN 1435-4373.

Han, F.C.; Ng, H.C. \& Ho, B. (2003). Stability of randomly amplified polymorphic DNA fingerprinting in genotyping clinical isolates of Helicobacter pylori. World Journal of Gastroenterology, Vol.9, No.9, (September 2009), pp. 2021-2024, ISSN 1007-9327.

Harris, P.R.; Mobley, H.L.; Perez-Perez, G.I.; Blaser, M.J. \& Smith, P.D. (1996). Helicobacter pylori urease is a potent stimulus of mononuclear phagocyte activation and inflammatory cytokine production. Gastroenterology, Vol.111, No.2, (August 1996), pp. 419-425, ISSN 0016-5085.

Herrera, V. \& Parsonnet, J. (2009). Helicobacter pylori and gastric adenocarcinoma. Clinical Microbiology and Infection, Vol. 15, No.11, (November 2009), pp. 971-976, ISSN 14690691.

Höcker, M. \& Hohenberger, P. (2003). Helicobacter pylori virulence factors - one part of a big picture. Lancet, Vol.362, No. 9391, (October 2003), pp. 1231-1233, ISSN 0140-6736.

Hoehnberger, P. \& Gretschel, S. (2003). Gastric cancer. Lancet, Vol.362, No.9380, (July 2003), pp. 305-315, ISSN 0140-6736. 
Huang, J.Q.; Zheng, G.F.; Sumanac, K.; Irvine, E.J. \& Hunt, R.H. (2003). Meta-analyisis of the relationship between cagA seropositivity and gastric cancer. Gastroenterology, Vol. 125, No.6, (December 2003), pp. 1636-1644, ISSN 0016-5085.

Husson, M.O.; Gottrand, F.; Vachee, A.; Dhaenens, L.; de la Salle, E.M.; Turck, D.; Houcke, M. \&Leclerc, H. (1995). Importance in diagnosis of gastritis of detection by PCR of the cagA gene in Helicobacter pylori strains isolated from children. Journal of Clinical Microbiology, Vol.33, No.12, (December 1995), pp. 3300-3303, ISSN 1098-660X.

International Agency for Research on Cancer. Schistosomes, liver flukes and Helicobacter pylori. IARC Working Group on the Evaluation of Carcinogenic Risks to Humans. IARC monographs on the evaluation of carcinogenic risks to humans. World Health Organization, International Agency for Research on Cancer, Vol.61, pp. 1-241.

Isaeva, G.Sh.; Abuzarova, E.R.; Valeeva, Iu.V.; Pozdeev, O.K. \& Murav'eva, E.V. (2009). Helicobacter pylori in patients with disorders of hepatobiliary system. Zhurnal Mikrobiologii Epidemiologii i Immunobioogiil, Vol.2, (March-April), pp. 96-101, ISSN 0378-9311.

Kabir, S. (2009). Effect of Helicobacter pylori eradication on incidence of gastric cancer in human and animal models: underlying biochemical and molecular events. Helicobacter, Vol.14, No.3, (June 2009), pp. 159-171, ISSN 1523-5378.

Kodaira, M.S.; Escobar, A.M.U. \& Grisi, S. (2002). Aspectos epidemiológicos do Helicobacter pylori na infância e adolescência. Revista de Saúde Pública, Vol.36, pp. 356-369, ISSN 0034-8910.

Kuipers, E.J.; Perez-Perez, G.I.; Meuwissen, S.G. \& Blaser, M.J. (1995). Helicobacter pylori and atrophic gastritis. Importance of the cagA status. Journal of the National Cancer Institute, Vol.87, No.23, (December 1995), pp. 1777-1780, ISSN 0027-8874.

Kusters, J.G.; van Vliet, A.H.M \& Kuipers, E.J. (2006). Pathogenesis of Helicobacter pylori infection. Clinical Microbiology Reviews, Vol.19; No.3, (July 2006), pp. 449-490, ISSN 1098-6618.

Lage, A.P.;Godfroid, P.; Fauconnier, A., Burette, A.; Butzler, J.P.; Bollen, A. \& Glupczynski, Y. (1995). Diagnosis of Helicobacter pylori infection by PCR: comparison with other invasive techniques and detection of cagA gene in gastric biopsy specimens. Journal of Clinical Microbiology, Vol.33, No.10, (October 1995), pp. 2752-2756, ISSN 1098660X.

Lauren, P. (1975). The two histological main types of gastric carcinoma: Diffuse and socalled intestinal type carcinoma. Acta Pathologica et Microbiologica Scandinavica, Vol.64, (1975), pp. 31-49, ISSN 0365-5571.

Leanza, A.G.; Matteo, M.J.; Crespo, O.; Antello, P.; Olmos, J.; \& Catalano, M. (2004). Genetic characterization of Helicobacter pylori isolates from na Argentinean adult population based on cag pathogenicity island right-end motifs, IspA-glmM polymorphism and iceA and vacA genotypes. Clinical microbiology and infection, Vol.10, No.9, (September 2004), pp. 811-819, ISSN 1469-0691.

Lu, H.; Hsu, P.; Graham, D.Y. \& Yamaoka, Y. (2005). Duodenal ulcer promoting gene of Helicobacter pylori. Gastroenterology, Vol.128, No.4, (April 2005), pp. 844-848, ISSN 0016-5085.

Lu, H.; Wu, J.Y.; Beswick, E.J.; Ohno, T.; Odenbreit, S., Haas, R.; Reyes, V.E.; Kita, M.; Graham, D.Y. \& Yamaoka, Y. (2007). Functional and intracellular signaling differences associated with the Helicobacter pylori AlpAB adhesin from Western and 
East Asian strains. The Journal of Biological Chemistry, Vol.282, No.9, (March 2007), pp. 6242-6254, ISSN 1083-351X.

Malfertheiner, P.; Bornschein, J. \& Selgrad, M. (2010). Role of Helicobacter pylori infection in gastric cancer pathogenesis: a chance for prevention. Journal of Digestive Diseases, Vol.11, No.1, (February 2010), pp. 2-11, ISSN 1751-2972.

Marshall, B.J., \& Warren, J.R. (1984). Unidentified curved bacilli in the stomach of patients with gastritis and peptic ulceration. Lancet, Vol.1, No.8390, (June 1984), pp. 13111315, ISSN 0140-6736.

Mattar, R.; Marques, S.B.; Monteiro, M.S.; Santos, A.F.; Iriya, K. \& Carrilho, F.J. (2007) Helicobacter pylori cag pathogenicity island genes: clinical relevance for peptic ulcer disease development in Brazil. Journal of Medical Microbiology, Vol.56, No.1, (January 2007), pp. 9-14, ISSN 1473-5644.

McClain, M.S.; Shaffer, C.L.; Israel, D.A.; Peek Jr, R.M. \& Cover, T.L. (2009). Genome sequence analysis of Helicobacter pylori strains associated with gastric ulceration and gastric cancer. BMC Genomics, Vol.10, (January 2009), pp. 3-16, ISSN 1471-2164.

Miehlke, S.; Kirsch, C.; Agha-Amiri, K.; Günther, T.; Lehn, N.; Malfertheiner, P.; Stolte, M.; Ehninger, G. \& Bayerdörffer, E. (2000). The Helicobacter pylori vacA s1, m1 genotype and cagA is associated with gastric carcinoma in Germany. International Journal of Cancer, Vol.87, No.3, (August 2000), pp. 322-327, ISSN 1097-0215.

Mizushima, T.; Sugiyama, T; Komatsu, Y.; Ishituza, J.; Kato, M. \& Asaka, M. (2001). Clinical relevance of the babA2 genotype of Helicobacter pylori in Japanese clnical isolates. Journal of Clinical Microbiology, Vol.39, No.7, (July 2001), pp.2463-2465, ISSN 1098$660 X$.

Moore, R.A.; Kureishi, A.; Wong, S. \& Bryan, L.E. (1993). Categorization of clinical isolates of Helicobacter pylori on the basis of restriction digest analyses of polymerase chain reaction-amplified ureC genes. Journal of Clinical Microbiology, Vol.31, No.5, (May 1993), pp. 1334-1335, ISSN 1098-660X.

Nardone, G. Rocco, A. \& Malfertheiner, P. (2004). Review article: Helicobacter pylori and molecular events in precancerous gastric lesions. Alimentary pharmacology $\mathcal{E}$ therapeutics, Vol.20, No.3, (August 2004), pp. 261-270, ISSN 0269-2813.

Nguyen, L.T.; Uchida, T.; Kuroda, A.; Tsukamoto, Y.; Trinh, T.D.; Ta, L.; Mai, H.B.; Ho, D.Q.; Hoang, H.H.; Vilaichone, R.K.; Mahachai, V.; Matsuhisa, T.; Kudo, Y.; Okimoto, T.; Kodama, M.; Murakami, K.; Fujioka, T.; Yamaoka, Y. \& Moriyama, M. (2009). Evaluation of the anti-East Asian CagA-specific antibody for CagA phenotyping. Clinical and vaccine immunology, Vol.16, No.11, (November 2009), pp. 1687-1692, ISSN 1556-679X.

Oh, J.D.; Kling-Backhed, H.; Giannakis, M.; Xu, J.; Fulton, R.S; Fulton, L.A.; Cordum, H.S.; Wang, C.; Elliott, G.; Edwards, J.; Mardis, E.R.; Engstrand, L.G. \& Gordon, J.L. (2006). The complete genome sequence of a chronic atrophic gastritis Helicobacter pylori strain: evolution during disease progression. Proceedings of the National Academy of Sciences of the United States of America, Vol.103, No.26, (June 2006), pp. 9999-1004, ISSN 1091-6490.

Parsonnet, J.; Friedman, G.D.; Orentreich, N. \& Vogelman, H. (1997). Risk for gastric cancer in people with CagA positive or CagA negative Helicobacter pylori infection. Gut, Vol.40, No.3, (March 1997), pp. 297-301, ISSN 1468-3288. 
Peek, R.M.; Blaser, M.J.; Mays, D.J.; Forsyth, M.H.; Cover, T.L; Song, S.Y.; Krishna, U. \& Pietenpol, J.A. (1999). Helicobacter pylori strain-specific genotypes and modulation of the gastric epithelial cell cycle. Cancer Research, Vol.59, No.24, (December 1999), pp. 6124-6131, ISSN 1538-7445.

Peek Jr, R.M. \& Blaser, M.J. (2002). Helicobacter pylori and gastrointestinal tract adenocarcinomas. Nature Reviews. Cancer, Vol.2, No.1, (January 2002), pp. 28-37, ISSN 1474-175X.

Pellicano, R.; Franceschi, F.; Saracco, G.; Fagoonee, S.; Roccarina, D. \& Gasbarrini, A. (2009). Helicobacters and extragastric diseases. Helicobacter, Vol.14, Suppl.1, (September 2009), pp. 58-68, ISSN 1523-5378.

Pirouz, T.; Zounubi, L.; Keivani, H.; Rakhshani, N. \& Hormazdi, M. (2009). Detection of Helicobacter pylori in paraffin-embedded specimens from patients with chronic liver diseases, using the amplification method. Digestive Diseases and Sciences, Vol.54, No.7 (July 2009), pp. 1456-1459, ISSN 1573-2568.

Qiao, W.; Hu, J.; Xiao, B.; Wu, K.C.; Peng, D.R.; Atherton, J.C. \&Xue, H. (2003). CagA and vacA genotype of Helicobacter pylori associated with gastric diseases in Xi'an area. World Journal of Gastroenterology, Vol.9, No.8, (August 2003), pp. 1762-1766, ISSN 1007-9327.

Roesler, B.M.; Oliveira, T.B.; Bonon, S.H.A.; Monici, L.T.; Zeitune, J.M.R. \& Costa, S.C.B. (2009). Restriction fragment length polymorphism of urease $C$ and urease $B$ gene of Helicobacter pylori strains isolated from Brazilian patients with peptic ulcer and chronic gastritis. Digestive Diseases and Sciences, Vol.54, No.7, (July 2009), pp. 14871493, ISSN 1573-2568.

Rohde, M.; Püls, J.; Buhrdorf, R.; Fischer, W. \& Haas, R. (2003). A novel sheated surface organelle of the Helicobacter pylori cag type IV secretion system. Molecular Microbiology, Vol.49, No.1, (July 2003), pp. 219-234, ISSN 1365-2958.

Rothenbacher, D.; Bode, G.; Berg, G.; Gommel, R.; Gonser, T.; Adler, G. \& Brenner, H. (1998). Prevalence and determinants of Helicobacter pylori infection in preschool children: a population-based study from Germany. International Journal of Epidemiology, Vol.27, No.1, (February 1998), pp. 135-141, ISSN 1464-3685.

Saiki, R.K.; Gelfand, D.H.; Stoffel, S.; Scharf, S.J.; Higuchi, R.; Horn, G.T.; Mullis, K.B. \& Erlich, H.A. (1981). Primer-directed enzymatic amplification of DNA with a termostable DNA polymerase. Science, Vol.239, No.4839, (January 1981), pp. 487491, ISSN 1095-9203.

Schmidt, H.M.A.; Andres, S.; Kaakoush, N.O.; Engstrand, L.; Eriksson, L.; Goh, K.L.; Fock, K.M.; Hilmi, I.; Dhamodaran, S.; Forman, D. \& Mitchell, H. (2009). The prevalence of duodenal ulcer promoting gene (dupA) in Helicobacter pylori isolates varies by ethnic group and is not universally associated with disease development: a casecontrol study. Gut Pathogens, Vol.1, No.1, (March 2009), pp. 5-13, ISSN 1757-4749.

Sugiyama, T. \& Asaka, M. (2004). Helicobacter pylori infection and gastric cancer. Medical Electron Microscopy, Vol.37, No.3, (September 2004), pp. 149-157, ISSN 1437-773X.

Telford, J.L.; Ghiara, P.; Dell'Orco, M.; Comanducci, M.; Burroni, D.; Bugnoli, M.; Tecce, M.F.; Censini, S.; Covacci, A. \& Xiang, Z. (1994). Gene structure of the Helicobacter pylori cytotoxin and evidence of its key role in gastric disease. The Journal of Experimental Medicine, Vol.179, No.5, (May 1994), pp. 1653-1658, ISSN 1540-9538. 
Thiberge, J.M.; Boursaux-Eude, C.; Lehours, P.; Dillies, M.A.; Creno, S.; Coppée, Y.; Rouy, Z.; Lajus, A.; Ma, L.; Burucoa, C.; Ruskoné-Foumestraux, A.; Courillon-Mallet, A.; De Reuse, H.; Boneca, I.G.; Lamarque, D.; Mégraud, F.; Delchier, J.C.; Médigue, C.; Bouchier, C.; Labigne, A. \& Raymond, J. (2010). From array-based hybridization of Helicobacter pylori isolates to the complete genome sequence of an isolate associated with MALT lymphoma. BMC Genomics, Vol.11, (June 2010), pp. 368-379, ISSN 14712164.

Thomazini, C.M.; Pinheiro, N.A.; Pardini, M.I.; Naresse, L.E. \& Rodrigues, M.A.M. (2006). Infecção por Helicobacter pylori e câncer gástrico: frequência de cepas patogênicas cagA e vacA em pacientes com câncer gástrico. Jornal Brasileiro de Patologia e Medicina Laboratorial, Vol.42, No.1, pp. 25-30, ISSN 1676-2444.

Tomb, J.F.; White, O.; Kerlavage, A.R.; Clayton, R.A.; Sutton, G.G.; Fleischmann, R.D.; Ketchum, K.A.; Klenk, H.P.; Gill, S.; Dougherty, B.A.; Nelson, K.; Quackenbush, J.; Zhou, L.; Kirkness, E.F.; Peterson, S.; Loftus, B.; Richardson, D.; Dodson, R.; Khalak, H.G.; Glodek, A.; McKenney, K.; Fitzegerald, L.M.; Lee, N.; Adams, M.D.; Hickey, E.K.; Berg, D.E.; Gocayne, J.D.; Utterback, T.R.; Peterson, J.D.; Kelley, J.M.; Cotton, M.D.; Weidman, J.M.; Fujii, C.; Bowman, C.; Watthey, L.; Wallin, E.; Hayes, W.S.; Borodovsky, M.; Karp, P.D.; Smith, H.O.; Fraser, C.M. \& Venter, J.C. (1997). The complete genome sequence of the gastric pathogen Helicobacter pylori. Nature, Vol.388, No.6642, (August 1997), pp. 539-547, ISSN 0028-0836.

Truong, B.X.; Mai, V.T.; Tanaka, H.; Ly le, T.; Thong, T.M.; Hai, H.H.; Van Long, D.; Furumatsu, K.; Yoshida, M.; Kutsumi, H. \& Azuma T. (2009). Diverse characteristics of the cagA gene of Helicobacter pylori strains collected from patients from southern Vietnam with gastric cancer and peptic ulcer. Journal of Clinical Microbiology, Vo.47, No.12, (December 2009), pp. 4021-4028, ISSN 1098-660X.

Tummuru, M.K.;Cover, T.L. \& Blaser, M.J. (1993). Cloning and expression of a highmolecular-mass major antigen of Helicobacter pylori: evidence of linkage to cytotoxin production. Infection and immunity, Vol. 61, No.5, (May 1993), pp. 1799-1809, ISSN 1098-5522.

vanDoor, L.J.; Figueiredo, C.; Sanna, R.; Plaisier, A., Schneeberger, P. de Boer, W. \& Quint, W. (1998). Clinical relevance of the cagA, vacA and iceA status of Helicobacter pylori. Gastroenterology, Vol.115, No.1, (July 1998), pp. 58-66, ISSN 0016-5085.

Yamaoka, Y.; Kodama, T.; Gutierrez, O.; Kim, J.G.; Kashima, K. \& Graham, D. (1999). Relationship between Helicobacter pylori iceA, cagA and vacA status and clinical outcome: studies in four different countries. Journal of Clinical Microbiology, Vol.37, No.7, (July 1999), pp. 2274-2279, ISSN 1098-660X.

Yamaoka, Y. (2008). Roles of the plasticity regions of Helicobacter pylori in gastroduodenal pathogenesis. Journal of Medical Microbiology, Vol.57, No.5, (May 2008), pp. 545-553, ISSN 1473-5644.

Zhang, Z.; Zheng, Q.; Chen, X.; Xiao, S.; Liu, W. \& Lu, H. (2008). The Helicobacter pylori duodenal ulcer promoting gene, dupA in China. BMC Gastroenterology, Vol.8, (October 2008), pp. 49-54, ISSN 1471-230X.

Zhou, J.; Zhang, J.; Xu, C. \& He, L. cagA genotype and variants in Chinese Helicobacter pylori strains and relationship to gastroduodenal diseases. (2004). Journal of Medical Microbiology, Vol.53, No.3, (March 2004), pp. 231-235, ISSN 0022-2615. 


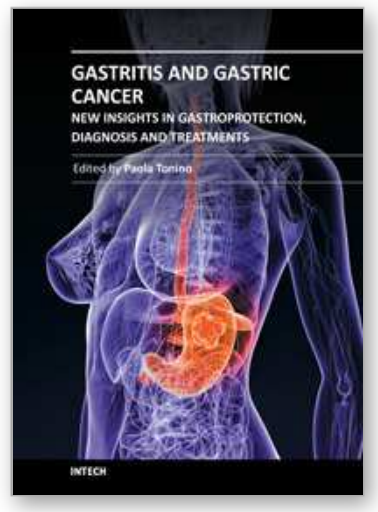

\section{Gastritis and Gastric Cancer - New Insights in Gastroprotection, Diagnosis and Treatments}

Edited by Dr. Paola Tonino

ISBN 978-953-307-375-0

Hard cover, 296 pages

Publisher InTech

Published online 15, September, 2011

Published in print edition September, 2011

This book is a comprehensive overview of invited contributions on Helicobacter pylori infection in gastritis and gastric carcinogenesis. The first part of the book covers topics related to the pathophysiology of gastric mucosal defense system and gastritis including the gastroprotective function of the mucus, the capsaicinsensitive afferent nerves and the oxidative stress pathway involved in inflammation, apoptosis and autophagy in $\mathrm{H}$. pylori related gastritis. The next chapters deal with molecular pathogenesis and treatment, which consider the role of neuroendocrine cells in gastric disease, DNA methylation in $\mathrm{H}$. pylori infection, the role of antioxidants and phytotherapy in gastric disease. The final part presents the effects of cancer risk factors associated with $\mathrm{H}$. pylori infection. These chapters discuss the serum pepsinogen test, $\mathrm{K}$-ras mutations, cell kinetics, and $\mathrm{H}$. pylori lipopolysaccharide, as well as the roles of several bacterial genes (cagA, cagT, vacA and dupA) as virulence factors in gastric cancer, and the gastrokine-1 protein in cancer progression.

\section{How to reference}

In order to correctly reference this scholarly work, feel free to copy and paste the following:

Bruna Maria Roesler, Sandra Cecillia Botelho Costa and José Murilo Robilotta Zeitune (2011). Virulence Factors of Helicobacter pylori and Their Relationship with the Development of Early and Advanced Distal Intestinal Type Gastric Adenocarcinoma, Gastritis and Gastric Cancer - New Insights in Gastroprotection, Diagnosis and Treatments, Dr. Paola Tonino (Ed.), ISBN: 978-953-307-375-0, InTech, Available from: http://www.intechopen.com/books/gastritis-and-gastric-cancer-new-insights-in-gastroprotection-diagnosis-andtreatments/virulence-factors-of-helicobacter-pylori-and-their-relationship-with-the-development-of-early-and-ad

\section{INTECH}

open science | open minds

\section{InTech Europe}

University Campus STeP Ri

Slavka Krautzeka 83/A

51000 Rijeka, Croatia

Phone: +385 (51) 770447

Fax: +385 (51) 686166

www.intechopen.com

\section{InTech China}

Unit 405, Office Block, Hotel Equatorial Shanghai

No.65, Yan An Road (West), Shanghai, 200040, China 中国上海市延安西路65号上海国际贵都大饭店办公楼405单元

Phone: +86-21-62489820

Fax: +86-21-62489821 
(C) 2011 The Author(s). Licensee IntechOpen. This chapter is distributed under the terms of the Creative Commons Attribution-NonCommercialShareAlike-3.0 License, which permits use, distribution and reproduction for non-commercial purposes, provided the original is properly cited and derivative works building on this content are distributed under the same license. 